\title{
How to explain the location of logistics warehouses from the urban quality-of-life index and the local supply index?
}

\author{
Leise Kelli de Oliveira ${ }^{a}$, Gracielle Gonçalves Ferreira de Araújo ${ }^{a}$, \\ Isabela Kopperschmidt de Oliveira ${ }^{\mathrm{a}}$
}

${ }^{a}$ Universidade Federal de Minas Gerais, Belo Horizonte - 31.515-212, Brazil

(C) 2019 Leise Kelli de Oliveira, Gracielle Goncalves Ferreira de Araujo, Isabela Kopperschmidt de Oliveira. This is an open access article distributed under the Creative Commons Attribution-NonCommercial-NoDerivs license (http://creativecommons.org/licenses/by-nc-nd/3.0/

DOI 10.2478/WSBJBF-2019-0018

\begin{abstract}
Warehouses are a fundamental element for the supply chain and, consequentially, provide resources for people to perform their daily tasks. Their location determines the type of goods movements that will be performed in the city area. Knowing their location is essential to define public policies applied to urban freight transport, city livability and economic development. In the search to make a better diagnosis of its area, the Belo Horizonte City Hall developed the urban quality-of-life index (UQLI) and the local supply index (LSI). This article used linear regression to identify the correlation amongst the UQLI, the LSI and the location of the logistics warehouses in urban areas. The best model obtained from the econometric analysis is the one that correlates warehouses with supermarkets, bookstores and stationery, residential area, quality of the house, bank and gas station. The results obtained were confirmed with spatial analysis. This result allows concluding that the warehouses are influenced by the favourable zoning, low land cost, proximity of regional and main streets of the city and high population and retailer density.
\end{abstract}

Keywords: Urban freight transport; Warehouse; location; linear regression; heat map; spatial analysis.

\section{Introduction}

Warehouses can be understood as the facilities where activities such as storage, repacking, labelling (Woudsuma et al., 2016) and transferring the cargo from vehicle to vehicle or from facility to vehicle (Andreoli et al., 2010). These locations have high levels of traffic, and the buildings are large, employing a small amount of people, considering their size (WOUDSUMA et al., 2016). They are one fundamental element for the supply chain (Giuliano \& Kang, 2018) and can be an urban freight traffic generator (Jaller et al., 2015). Besides their importance to the companies supply chain, the warehouses are vital to provide goods for people to perform daily tasks (Taniguchi, 2015).

The warehouses location impacts directly in the urban goods movements (Wygonil et al., 2015). Crainic et al. (2004) demonstrated the impact of these location and vehicle choice. Dablanc and Rakotonarivo (2010) complemented the previous study demonstrating that the further from the consumer centres these facilities are located, more $\mathrm{CO} 2$ will be released in the atmosphere, in reason of goods movement. The impact of warehouses in urban areas can be noticed in the increase of local traffic and congestions caused mainly by loading and unloading activities (Cidell, 2011).

\footnotetext{
${ }^{1}$ Corresponding author. Tel.: +55-31-3409-1742

E-mail address: leise@etg.ufmg.br 
It is important to know the location of the warehouses by urban planners to define public policies applied to urban freight transport, to the city livability and the economic development (Healey, 2006). The cost of transportation and the operational efficiency of their activities are fundamental for the companies, and the location has a direct impact on them (Lindsay et al., 2014). Therefore, they try to locate their facilities strategically close to their main consumer market (Bowen, 2008).

A literature review by Oliveira et al. (2019) demonstrated that, concerning warehouses location choice, there are six main factors studied: accessibility, land-use patterns, logistics costs, distance from consumers and suppliers, truck traffic conditions and land for expansion. The authors found that the first three factors are the most recurrent, demonstrating the importance of the location choosing process to achieve the most lucrative solution as possible.

In this context, this article analyses the correlation amongst the variables that make up the urban quality of life index (UQLI) and the local supply index (LSI) and the number of warehouses of the planning areas (PA) in Belo Horizonte. We intend to identify if these indexes explain the location of warehouses in urban areas. These indexes will be presented in the next section.

The method and results presented in this article allow us to infer how the location of warehouses is influenced by factors beyond those reported in the literature. However, a major challenge is the availability and obtainment of these data. Finally, the use of econometrics has not been explored to explain the location of the warehouses, being the research approach used in this study.

\section{Research Approach}

We used linear regression to identify the correlation between the UQLI and the LSI and the location of the logistics warehouse in urban areas.

\section{$2.1 \quad$ Definition of variables}

First, we defined the variables used in this article. We used open data from Belo Horizonte municipality. The UQLI has variables calculated from each PA (geographical unit) of Belo Horizonte. From the UQLI database, we selected the variables with potential to influence the location of warehouse. Table 1 summarises the variables, indicator composition and the importance of each to this analysis. Variables A1 and A2 are included in this table and refer to the main variable of this analysis, that is, warehouse. Figure 1 shows the PAs in Belo Horizonte.

Table 1. Summary of variables, indicator index and importance.

\begin{tabular}{|c|c|c|c|}
\hline Variable & Short name & Indicator Composition & Importance \\
\hline Warehouse & A1 & Quantity of warehouse & Main variable \\
\hline $\begin{array}{l}\text { Land price per square } \\
\text { metre of warehouse }\end{array}$ & $\mathrm{A} 2$ & Land price per square & $\begin{array}{l}\text { Represents the influence of land cost on } \\
\text { warehouse location }\end{array}$ \\
\hline Supermarkets & A3 & $\begin{array}{l}\text { (Quantity of supermarkets/population) } \times \\
1,000\end{array}$ & $\begin{array}{l}\text { Indicates the necessity of supplying the } \\
\text { population with goods }\end{array}$ \\
\hline $\begin{array}{l}\text { Bookstores \& } \\
\text { Stationery }\end{array}$ & A4 & $\begin{array}{l}\text { (Area of bookstores \& stationery/population) } \\
\times 1,000\end{array}$ & $\begin{array}{l}\text { Indicates the necessity of supplying the } \\
\text { population with goods }\end{array}$ \\
\hline Residential area & A5 & Square metre of residential area/population & $\begin{array}{l}\text { Evaluates income pattern of planning } \\
\text { area }\end{array}$ \\
\hline Quality of the house & A6 & Evaluation of the quality of the house & $\begin{array}{l}\text { Evaluates income pattern of planning } \\
\text { area }\end{array}$ \\
\hline Bank & A7 & Quantity of bank/population $\times 10,000$ & $\begin{array}{l}\text { Evaluates income pattern of planning } \\
\text { area }\end{array}$ \\
\hline Gas station & A8 & Quantity of gas station/population $\times 10,000$ & $\begin{array}{l}\text { Evaluates income pattern of planning } \\
\text { area }\end{array}$ \\
\hline $\begin{array}{l}\text { Local supply index } \\
\text { (LSI) }\end{array}$ & A9 & Aggregate indicator & $\begin{array}{l}\text { The measure of urban service offers in } \\
\text { planning area }\end{array}$ \\
\hline $\begin{array}{l}\text { Urban quality of life } \\
\text { index (UQLI) }\end{array}$ & A10 & $\begin{array}{l}\text { UQLI is obtained from the weighting of the } \\
\text { variables that make up the LSI by the } \\
\text { accessibility matrix }\end{array}$ & $\begin{array}{l}\text { Quantifies the availability of public and } \\
\text { private goods and services in Belo } \\
\text { Horizonte }\end{array}$ \\
\hline
\end{tabular}

\subsection{Econometrics analysis}

The first process was to describe the variables using descriptive statistics. Also, the variables presented in Table 1 were analysed by Spearman correlation to show statistical dependence amongst variables.

Linear regression was considered to identify models to explain the influence of variables in the location of warehouses. Washington et al. (2011) described the linear regression technique. We evaluated the accuracy of the model by t-test (model coefficient accuracy) and using p-value (model accuracy). The best models were identified by the coefficient of determination (R2) and Akaike information criterion (AIC). 


\subsection{Spatial analysis}

Considering the urban areas, we create a heat map showing the location of warehouses and the variables considered in this study to demonstrate the relationships identified in the econometrics model in the geographical space. In this analysis, we included the large facilities zoning.

\section{Results}

Table 2 present the descriptive statistics of the variables considered in this study. The number of warehouses varies from 1 to 11 by PA. Also, the price of land per square metre varies from BRL 2,000 until to BRL 11,868 $(1 \square \approx$ BRL 4.46 on 04 October 2019).

\begin{tabular}{lrrrrrr}
\multicolumn{2}{c}{ Table 2. Descriptive data. } \\
\hline Variables & Minimum & First quartile & Median & Mean & $\begin{array}{c}\text { Third } \\
\text { quartile }\end{array}$ & Maximum \\
\hline A1 & 0 & 0 & 0 & 1.025 & 1 & 11 \\
A2 & 0 & 0 & 2,022 & 2,059 & 2,942 & 11,868 \\
A3 & 0 & 0.09 & 0.15 & 0.17 & 0.21 & 1.38 \\
A4 & 0 & 8.53 & 24.37 & 122.24 & 61.36 & $4,371.93$ \\
A5 & 0.52 & 15.06 & 27.22 & 31.94 & 42.14 & 97.70 \\
A6 & 0.17 & 5.03 & 7.76 & 7.78 & 10.11 & 20.56 \\
A7 & 0 & 0.78 & 2.85 & 8.66 & 6.02 & 194.85 \\
A8 & 0 & 0 & 0.79 & 1.01 & 1.32 & 6.56 \\
A9 & 0.14 & 0.43 & 0.54 & 0.52 & 0.60 & 0.89 \\
A10 & 0.46 & 0.63 & 0.69 & 0.69 & 0.75 & 0.87 \\
\hline
\end{tabular}

Figure 1 shows the correlation amongst the variables. Variables A1 (warehouse) and A2 (land price) have weak correlation with other variables. In this way, these variables could be used in regression analysis.

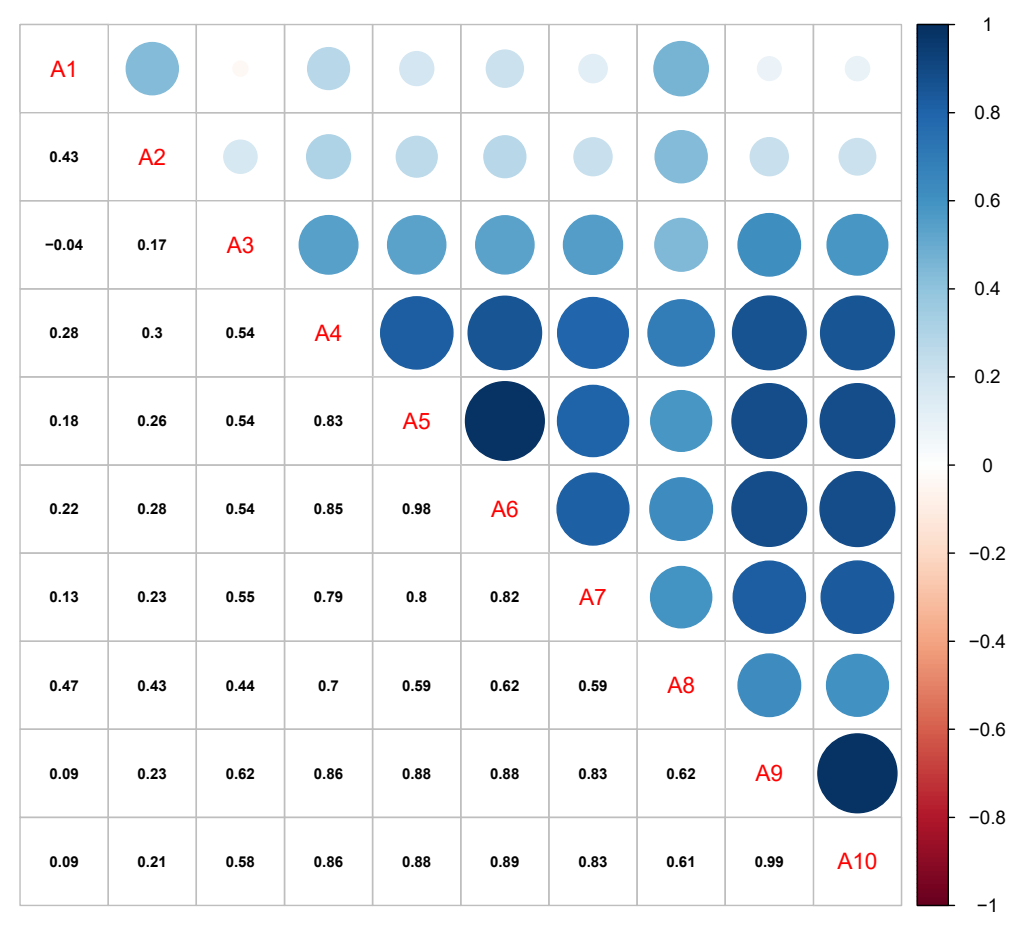

Fig. 1. Correlogram of variables.

Table 3 shows the models. Variable A1 (warehouse) is the dependent variable in all models. The model (2) correlating variables $\mathrm{A} 1$ with variables $\mathrm{A} 3-\mathrm{A} 8$ presented the best accuracy. In this sense, variables A3 (supermarkets), A5 (residential area) and A7 (bank) contribute negatively to the warehouse location in the PA. Supermarkets (variable A3) are large and have internal storage in Brazil. In addition, these have their own warehouses located in the metropolitan area. Thus, the negative influence of these establishments is explained by being part of the logistics infrastructure. Variable A5 (residential area) indicates land cost, considering the municipal land tax. In this case, Oliveira et al. (2019) showed that warehouses are located in regions where the land value is lower. Therefore, the negative influence is explained and justified for this reason. Finally, banks 
(variable A7) are located in densely populated areas, which are not permissible for the installation of warehouses, according to urban zoning.

\begin{tabular}{|c|c|c|c|c|c|c|}
\hline $\begin{array}{c}\text { ID } \\
\text { Model }\end{array}$ & Independent variable & Coefficient & t-test & $\mathrm{p}$-Value & $\mathrm{R}^{2}$ & AIC \\
\hline 1 & A2 & $3.107 \mathrm{e}-04$ & 4.645 & $1.356 \mathrm{e}-05$ & 0.22 & 318.17 \\
\hline \multirow[t]{6}{*}{2} & $\mathrm{~A} 3$ & -4.74 & -2.951 & $6.355 \mathrm{e}-12$ & 0.58 & 279.72 \\
\hline & A4 & 0.003 & 4.167 & & & \\
\hline & A5 & -0.079 & -4.057 & & & \\
\hline & A6 & 0.50 & 4.840 & & & \\
\hline & A7 & -0.06 & -3.464 & & & \\
\hline & A8 & 0.60 & 3.567 & & & \\
\hline 3 & A9 & 1.5366 & 5.403 & $6.84 \mathrm{e}-07$ & 0.27 & 312.33 \\
\hline 4 & A10 & 1.5005 & 5.402 & $6.922 \mathrm{e}-07$ & 0.27 & 312.35 \\
\hline
\end{tabular}

Figure 2(a) compares the location of warehouses and the large facilities zoning. We observe a concentration of warehouse around the regional highways and in the large facilities zoning. This is one important result because the local zoning to warehouse is almost considered in the location of these logistics facilities. However, we observe warehouses outside of this zoning, whose impacts could be negative and need to be considered to authorise its implementation. In addition, it is possible to notice that the warehouses are located near the central region, with a higher concentration of consumption because of population and trade density. Also, Figure 2(b) shows the warehouses that are located in areas where the supply of supermarket is low.

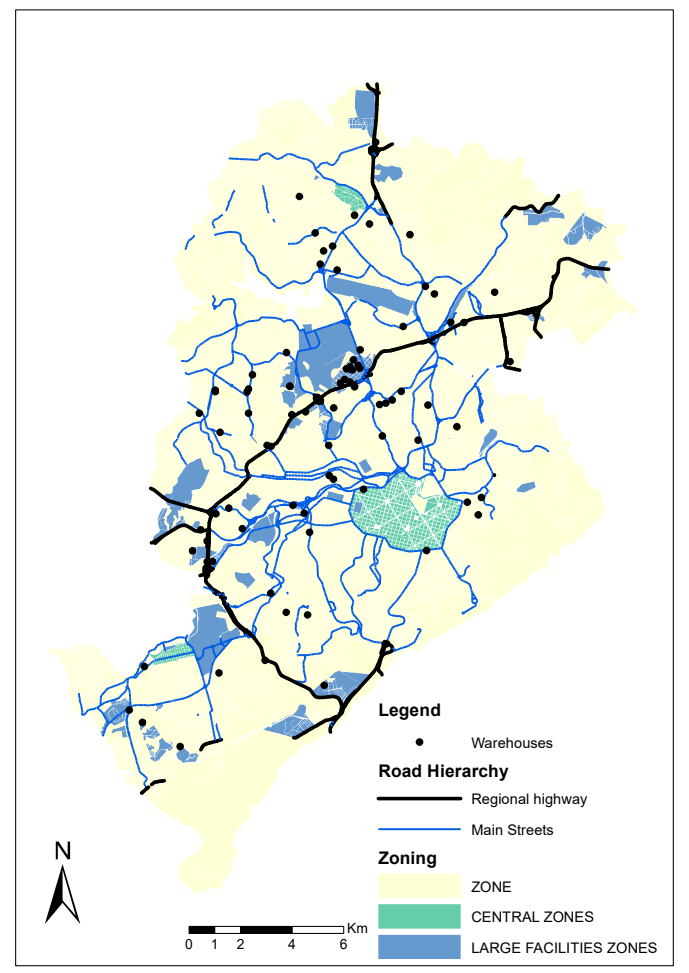

(a)

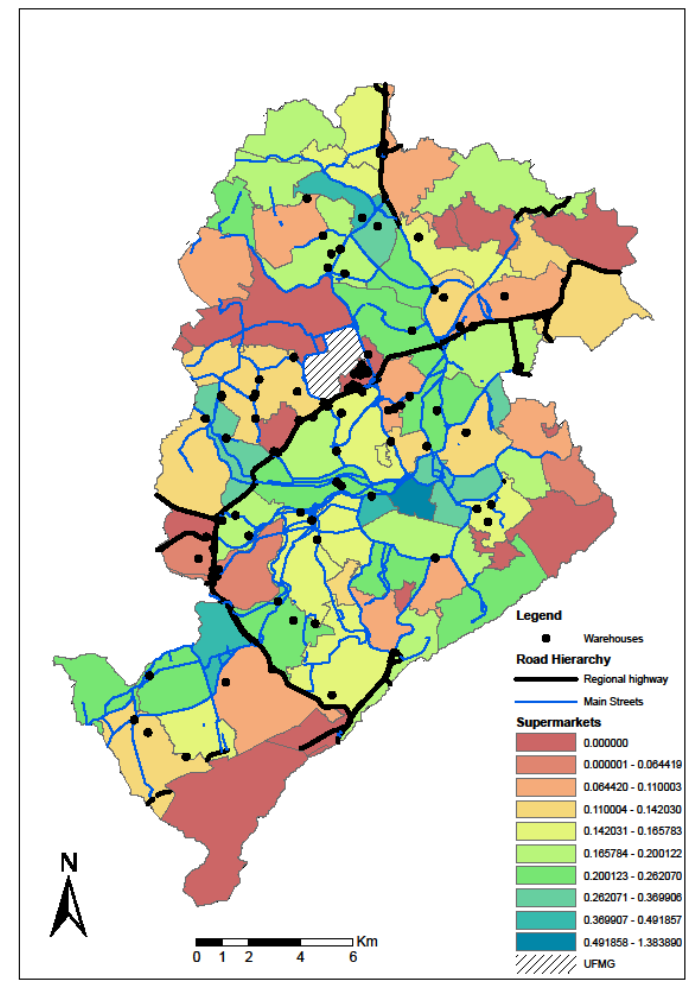

(b)

Fig. 2. Location of warehouses and heat map of large facilities zones (a) and supermarkets (b)

Also, in general, the location of warehouse is in areas not exclusively residential (Figure $3 \mathrm{a}$ ), whose quality of the house is low (Figure 3b). These variables indicate the location of the warehouse in areas with a low land cost. 


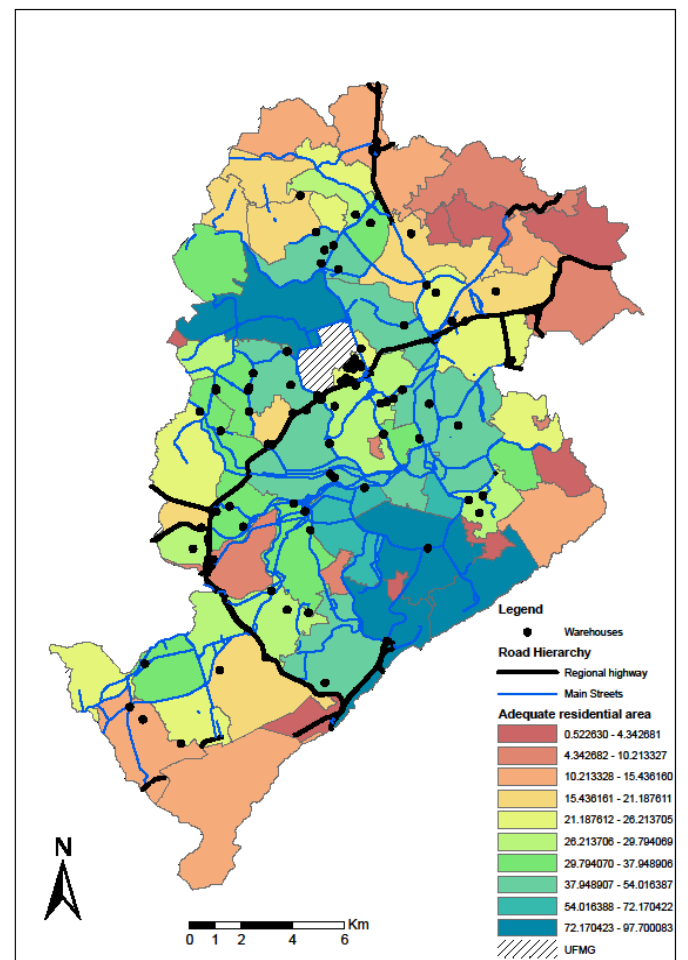

(a)

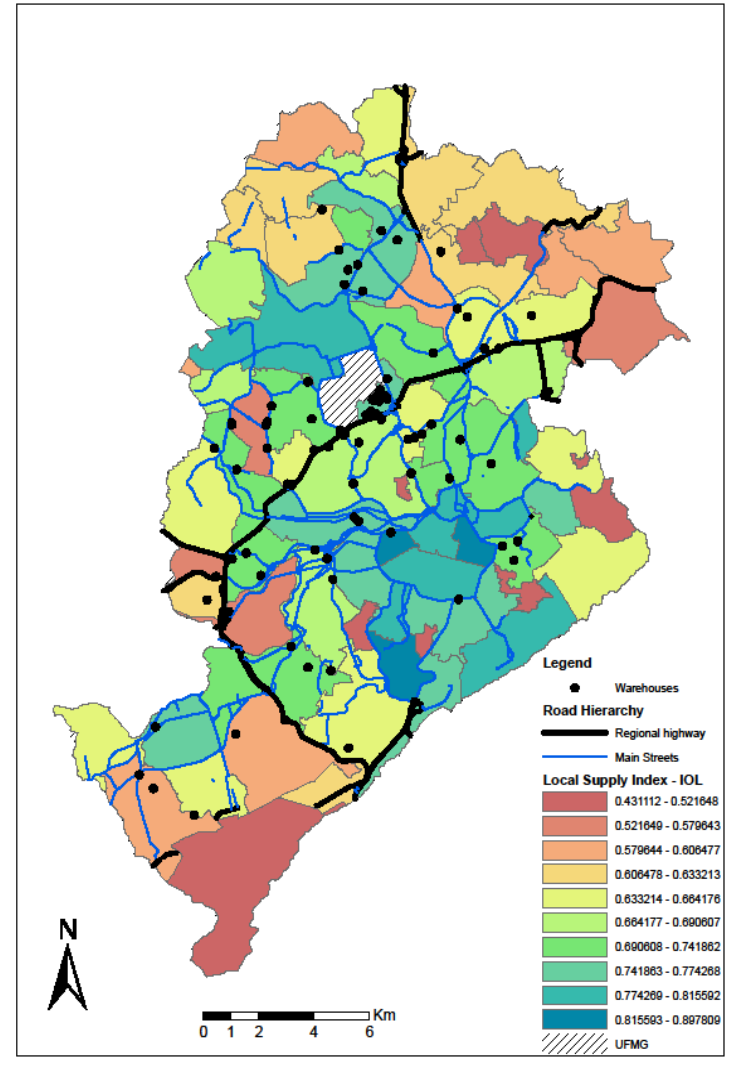

(c)

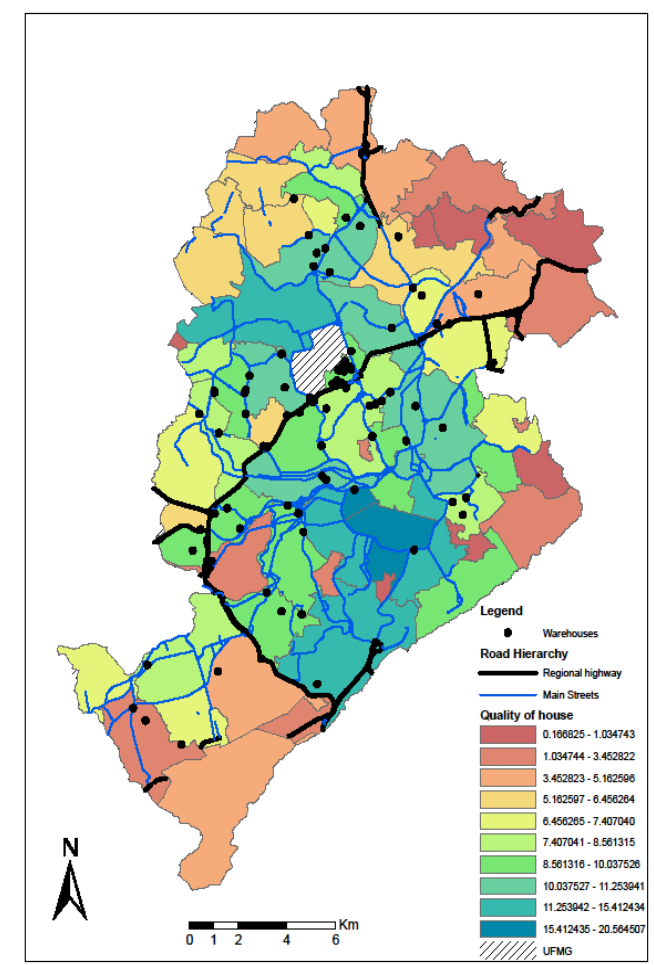

(b)

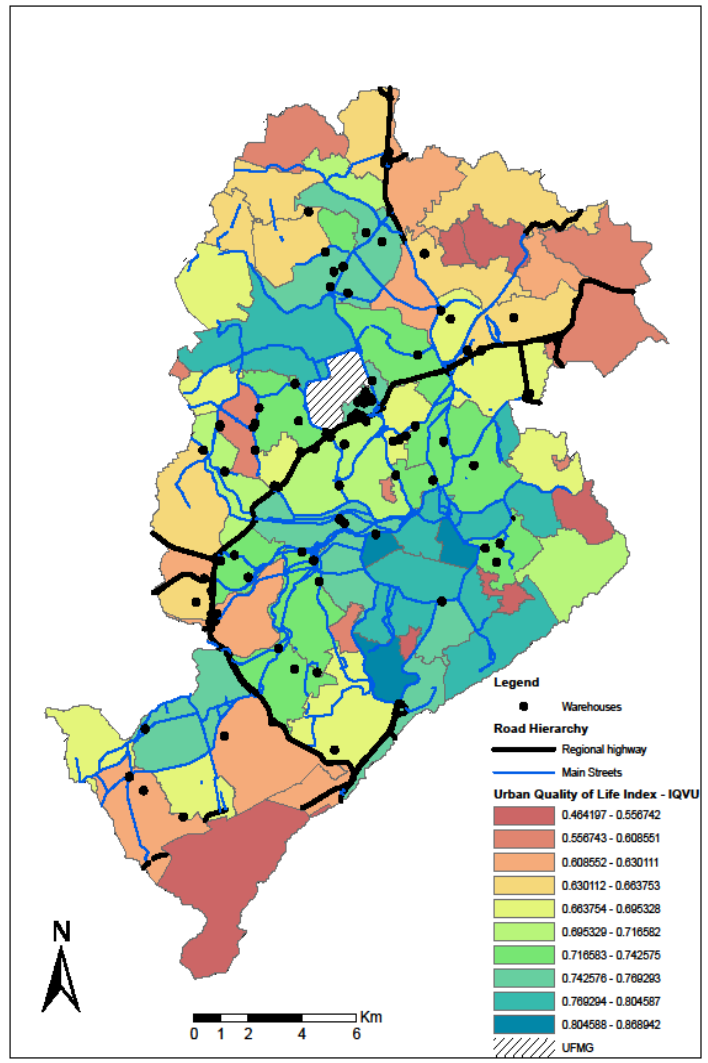

(c)

Fig. 3. Location of warehouses and heat map of residential area (a), quality of the house (b), local supply index (c) and urban quality life index (d).

Figure 3(c) shows the location of warehouse in areas with local supply. This result indicates that the warehouses are located closer to demand. Also, the warehouses are located in areas with good urban quality life index, indicating good accessibility. 


\section{Conclusion}

The results presented in this article allow concluding that the location of the warehouses is influenced by the favourable land-use, low land cost, proximity of regional highways and main streets of the city and high population and retailer density. Sakai et al. (2016) related challenges of the relationship between warehouse location and land use.

These results are important from the urban planning point of view because when the city identify specific areas for large facilities, it is possible to plan appropriate infrastructure for them, including urban roads, parking spaces and public policies to improve the mobility of urban goods. In this way, the large facilities zoning has a positive influence on the location of the warehouses.

Another interesting result is the influence of land cost on warehouse location, converging with literature (Jakubicek and Woudsma, 2011; Verhetsel et al., 2015; Aljohani and Thompson, 2017; Giuliano and Kang, 2018; Yuan, 20183). In Brazil, the real state does not accompany public policies, working as a private sector with private interests. In this sense, it is essential that large facilities zoning have adequate infrastructure for the location of warehouses. Also, the government needs to authorise the establishment of warehouses only in these locations, in order to enhance the accessibility and mobility of goods and land-use regulation.

\section{Acknowledgements}

The authors acknowledge the support of CNPq, CAPES and UFMG in this research.

\section{References}

Aljohani, K. \& Thompson, R. (2017) Impacts of logistics sprawl on the urban environment and logistics: Taxonomy and review of literature. Journal of Transport Geography, 57, p. 255-263. DOI: 10.1016/j.jtrangeo.2016.08.009

Cidell, J. (2011) Distribution centers among the rooftops: the global logistics network meets the suburban spatial imaginary. International Journal of Urban and Regional Research, 35(4), 832-851. DOI: 10.1111/j.14682427.2010.00973.x.

Crainic, T. G., Ricciardi, N. \& Storchi, G. (2004). Advanced freight transportation systems for congested urban areas. Transportation Research Part C: Emerging Technologies, 12, 119-137

Dablanc, L. \& Rakotonarivo, D. (2010). The impacts of logistical sprawl: how does the location of parcel transport terminals affect the energy efficiency of goods movements in Paris and what can we do about it?. Social and Behavioral Sciences - Procedia, 2(3), 6087-6069.

Giuliano, G. \& Kang, S. (2018). Spatial dynamics of the logistics industry: evidence from California. Journal of Transport Geography, 66, 248-258. DOI 10.1016/j.jtrangeo.2017.11.013

Healey, P. (2006) Transforming governance: challenges of institutional adaptation and a new politics space. European Planning Studies, 14(3), 299-320. DOI: 10.1080/0965310500420792.

Jakubicek P. \& Woudsma C. (2011) Proximity, land, labor and planning? Logistics industry perspectives on facility location. Transportation Letters: The International Journal of Transportation Research, 2, p. 161-173. DOI: 10.3328/TL.2011.03.03.161-173

Jaller, M., Wang, X. \& Holguín-Veras, J. (2015). Large urban freight traffic generators: opportunities for city logistic iniciatives. Journal of Transport and Land Use, 8(1), 1-17. DOI: 10.5198/jtlu.2015.406.

Lindsay, C., Mahmassani, H. S., Mullarkey, M., Nash, T. \& Rothberg, S. (2014) Industrial space demand and freight transportation activity: exploring the connection. Journal of Transport Geography, 37, 93-101. DOI: 10.1016/j.jtrangeo.2014.04.009

Oliveira, L. K., Lopes, G. P., Oliveira, R. L. M. \& Bracarense, L. S. F. P. (2019) Locational Context for Wharehoude Facilities in Urban Areas: A Case Study in Belo Horizonte (Brazil). In: 15th WCTR, Bombai.

Sakai T., Kawamura, K. \& Hyodo, T. (2016) Logistics facility distribution in Tokyo Metropolitan area: Experiences and policy lessons. Transportation Research Procedia, 12, 263-277. DOI 10.1016/j.trpro.2016.02.064

Taniguchi, E. (2015) City Logistics for Sustainable and Liveable Cities. Green Logistics and Transportation, 4 , 49-60. DOI: 10.1007/978-3-319-17181-4.

Verhetsel A., Kessels R., Goos P., Zijlstra T., Blomme N., \& Cant J. (2015) Location of logistics companies: a stated preference study to disentangle the impact of accessibility. Journal of Transport Geography, 42, p. 110121

Washington, S., Karlaftis, F. \& Mannering, M. (2011) Statistical and econometric methods for transportation data analysis. Chapman \& Hall/CRC: Boca Raton.

Woudsuma, C., Jakubicek, P. \& Dablanc, L.(2016). Logistic sprawl in North America: Methodological issues and a case study in Toronto. Transportation Research Procedia, 12, 474-488. DOI: 10.1016/j.trpro.2016.02.081. 
Wygonik, E., Bassok, A., Goodchild, A., McCormack, E. \& Carlson, D. (2015). Smart growth and goods movement: emerging research agendas. Journal of Urbanism: International Research on Placemaking and Urban Sustainability, 8 (2). 115-132. DOI: 10.1080/17549175.2013.875058.

Yuan, Q. (2018) Environmental Justice in Warehousing Location: State of the Art. Journal of Planning Literature, 33(3), p. 287-298. DOI 10.1177/0885412217753841 